\title{
Multiplication of Mycobacterium lepraemurium in cell-free liquid medium
}

5. Establishment of NC-5 medium

\author{
MASAHIRO NAKAMURA \\ (Department of Microbiology, Kurume University School of Medicine)
}

In the present paper, it was described that newly improved cell-free culture medium, referred to as NC-5, permitted more abundant multiplication of $M$. lepraemurium than that of NC-3 medium which was previously reported. The NC-5 medium was established by the method in which 1 -cysteine $\mathrm{HCl}$ was added to NC-3 medium. Optimal concentration of 1 -cysteine $\mathrm{HCl}$ to be added was $0.03 \%$. When three strains of $M$. lepraemurium, Hawaii, Kurume No. 42, and Kumamoto, were inoculated to and cultivated in NC-5 medium at $30^{\circ} \mathrm{C}$, these strains easily multiplied, whereas there were some differences of growth abilities among the three strains in the case of NC medium. 


\title{
無細胞液体培地における鼠嬾菌の増菌
}

第 5 報 NC-5 培地の開発

\author{
中 村昌弘 \\ (久留米大学医学部微生物学教室細菌学講座)
}

（受付 1973年 7 月20日）

前報1において $\mathrm{NC}$ 培地223) と呼称する無細胞培地を改 良した NC-3培地を記載したが，本報では NC-3培地に 更に改良を加えた NC-5培地を創案したのでここに報告 する。NC-5 培地の培地組成などについては短報425)とし てすでに報告したが，ここではその調整法の詳細を報告 する予定である。

このNC-5 培地では NC-3 培地より更に再現性ある鼠 瀨菌の增菌像がえられ，菌数增加も著明である。

\section{材料と方法}

供試鼠攋菌： $\mathrm{C}_{3} \mathrm{H}$ マウス皮下に継代された八ワイ株・ 久留米 42 号株扝よび熊本株の 3 株を用いた。鼠濑腫を無 菌的にとり出し，シャーレ中でハサミで細切，滅菌蒸溜 水約 $10 \mathrm{ml}$ を注ぎ，試験管に移し，ピペットで pipetting して菌浮遊液を作製。一晚, 水室に静置, 上清を 実験材料として使用した。普通はこの上清を更に20倍か ら50倍に蒸溜水で希釈して用いた。

增菌観察法：たて切りスライドをシリコンでカバーし たいわゆるシリコン・スライドに菌液を注射器で一滴々 下。約30分放圆，菌液を注射器で軽く吸い取った。この 際，菌液が滴下面全般に円形にわずかに残る程度に吸い 取る方があり増菌度観察に便である。余り完全に菌液 を吸い取ると，菌数が少ないせいか， microcolony は形 成しても肉眼で增菌度を镜察するには適しない。菌液が 乾いて白い円形斑が認められたら菌塗抹端を下部にして 直ちに培地に投入し，ゴム栓で密栓し， $30^{\circ} \mathrm{C}$ で培養す る。普通は1カ月毎にスライドを取り出し，10\%ホルマ リン水中に投入して $2 \sim 3$ 分固定した後, 水洗, ZiehlNeelsen 染色を施して菌形・菌増加度を観察し, 増菌 率を決定した。場合によっては1週閒每, あるいは 2 週 間毎にスライドを取り出し, 経時的菌形変化の観察む行 なった。一枚は培地へ投入しないで，10\%ホルマリン水 一投入，固定，“ “ 0 ” time の菌形，菌数の観察に供し
た。

NC-5 培地の調整法 : 基礎培地 (EKP) と添加物より 成る。

1）基礎培地（EKP）:

第 1 燐酸力リ $\left(\mathrm{KH}_{2} \mathrm{PO}_{\mathbf{4}}\right)$ (和光特級) $6.0 \mathrm{~g}$

第 2 燐酸ソーダ $\left(\mathrm{Na}_{2} \mathrm{HPO}_{4} \cdot 12 \mathrm{H}_{2} \mathrm{O}\right)$

(和光，特級） $6.0 \mathrm{~g}$

クエン酸ソーダ $\left(\mathrm{C}_{6} \mathrm{H}_{5} \mathrm{O}_{7} \mathrm{Na}_{3} \cdot 2 \mathrm{H}_{2} \mathrm{O}\right)$

(和光, 特級) $3.7 \mathrm{~g}$

グルタミン酸ソーダ（和光・特級） $15.0 \mathrm{~g}$

硫酸マグネシウム $\left(\mathrm{MgSO}_{4} \cdot 7 \mathrm{H}_{2} \mathrm{O}\right)$

(和光・特級) $0.9 \mathrm{~g}$

グリセリン（和光・特級） $30 \mathrm{ml}$

グルニース (和光・特級) $4.0 \mathrm{~g}$

焦性ブドウ酸ソーダ (片山化学) $5.0 \mathrm{~g}$

$\mathrm{Aq}$ を加えて $1,000 \mathrm{ml}$ として加温溶解, $20 \% \mathrm{Na}$ $\mathrm{OH}$ でpH 7.3 に補正（この状態でフリーザ保存 可)

以上の培地 $5 \mathrm{Vol}$.に0.5\% (w/v) パントテン酸カル シウム水溶液 (和光・純薬) $0.1 \mathrm{Vol}$. 加え, 下記 の添加物の量を考虑してコルベンに作製し, $115^{\circ} \mathrm{C}^{\prime}$ 10分間オートクレーブで減菌する。

2) 添加物 :

1) 山羊血清…1 1 Vol.

2) $2 \%(\mathrm{w} / \mathrm{v}) \alpha$-ケトグルタル酸（和光純薬） 水溶液…0.5 Vol.

3) $0.1 \%(w / v)$ チトクロームC（和光純薬） 水溶液…1 1 Vol.

4) ヘミン液…0.0. $0.5 \mathrm{Vol}$.

5) $0.3 \%(\mathrm{w} / \mathrm{v}) l$-システィン塩酸笽 (和光純薬) …0.2 $\mathrm{Vol}$.

以上を上記隇菌 $\mathrm{EKP}$ 培地に無菌的に加え, よく混 和, $8 \mathrm{ml}$ 宛を中型試験管 $(10.5 \times 1.3 \mathrm{~cm})$ に分注し, 
ヨ゙ム栓で密栓。

山羊血清は全採血により非無菌的に大コルベンに採 血, 一晚 $4^{\circ} \mathrm{C}$ に保ち, 遠心により血清公分離, ポア サイズ $8 \mu \mathrm{m}$ のミリポア・フィルターで濾過, そのあ と0.2 $2 \mu \mathrm{m}$ のミリポア・フィルター濾過で無菌にし, 更に5 $56^{\circ} \mathrm{C} 30$ 分 3 回の非衝化を行なったものを使用し た。 $4^{\circ} \mathrm{C}$ 保存

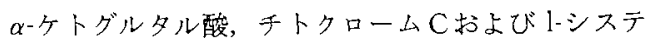
イン塩酸塩は再蒸溜水に溶解， $0.2 \mu \mathrm{m}$ のミリポア・ フィルターによって濾過滅菌， $4^{\circ} \mathrm{C}$ に保存。1-システ イン塩酸塩は永く保存すると沈澱を生じるので沈澱が 認められたら使用しない。

ヘミン液はへミン (Re-crystallized [NBC]) の80mg を $2 \mathrm{ml}$ ○ triethanolamine (和光一級) に溶解 L, Aq $8 \mathrm{~m}$ をを加ら。これを stock solution として $4^{\circ} \mathrm{C}$ 保存。これを $\mathrm{Aq}$ で100倍に希翻し、ミリポア・フィ ルターで濾過滅菌して $4^{\circ} \mathrm{C}$ 保存。この希勫へミンを培 地作製に用いる。

培地調整に当っては， $2 \mathrm{ml}$ および $5 \mathrm{ml}$ の滅菌メス ピペットを使用する。

\section{成 績}

\section{1・システィン塩酸塩の効果}

NC-3培地に，はじめは1-システィンを加えてその効 果を検討した。な㧍，その場合，NC-3より基礎培地に 含まれている7.5\%の萀糖を除いた NC-3 (-sucrose) も 同時に検愊し，蕉糖が必要かどうかの検討む加えた。

その結果は表1のと抢りであって，1-システィンの添 加は明らかに NC-3培地よりるすぐれていた。ただし， その添加量に至適があり最終濃度が0.01\%から0.001\% の閒が発育を促進し，0.1\%では阻止的に作用した。
また，蔴糖は必要でなくむしろ蔴糖を加えない方が 発育は良好であった。

ただ，1ーシスティンは不安定であり，約 2 週閒 $4^{\circ} \mathrm{C} の$ 保存の閒に白色の沈檓を生じるので，より安定な1ーシス ティン塩酸塩を用いることにした。従ってその添加量は 1-システィンの添加量より換算して，すでに述べた如く， $0.3 \%(\mathrm{w} / \mathrm{v})$ l-システィン塩酸塩を0.2Vol. 加えること にし， $0.1 \%$ 1-システィン $0.5 \mathrm{Vol}$. とほぼ同量の添加量 にした。

このようにして創案された培地を NC.5 培地と呼称 し実験方法の項で記載したものである。

2. 鼠瀨菌 3 株の NC-5培地での增殖

NC 培地に鼠瀨菌八ワイ株, 久留米株および熊本株を 培盖すると，それらは增殖度の間に著しい差があり，八 ワイ株は極めて良好な発育像を示すのに，他の2株の増 殖は著明でなかった。NC-3 培地ではその検討は行なっ ていない。

従ってここではこれら 3 株の NC-5培地での増殖の比 較を行なった。その結果は図 1 に示すと括りで，3株と も良好な増殖像を示したが，中でも八ワイ株および久留 米株の増殖は著明であつた。熊本株がやや増殖度が少っ た。

\section{考察}

NC-3 培地の改良を試みる手段として電子伝達系の中 で 1-システィンの添加を行なったところ，NC-3 培地に 優る再現性のよい鼠癩菌増殖用培地の開発に到達した。 これを NC-5 培地と呼称した。

本報では，しかし，スライドの鉒抹上の増菌像の形態 的観察のみでその判定を行なったので，今後菌数カウン 卜圭行なって菌数增加率も当然 NC-3培地のそれと比較

Table 1 Effect of 1-cysteine on the growth of $M$. lepraemurium in $\mathrm{NC}-3$ medium

\begin{tabular}{|c|c|}
\hline Culture medium & $\begin{array}{l}\text { Growth of } M \text {. lepraemurium } \\
\text { for } 2 \text { months cultivation }\end{array}$ \\
\hline $\mathrm{NC}-3$ & + \\
\hline NC-3 $+1 \% 1$-cysteine & - \\
\hline $\mathrm{NC}-3+0.1 \% \mathrm{I}$-cysteine & H \\
\hline NC-3+0.001\% 1-cysteine & Hit \\
\hline NC-3 (- sucrose) & + \\
\hline NC-3 (- sucrose $)+1 \%$ 1-cysteine & - \\
\hline NC-3 (-sucrose $)+0.1 \% 1$-cy teine & H \\
\hline NC.3 (-sucrose $)+0.01 \% 1$-cyssteine & 册 \\
\hline
\end{tabular}




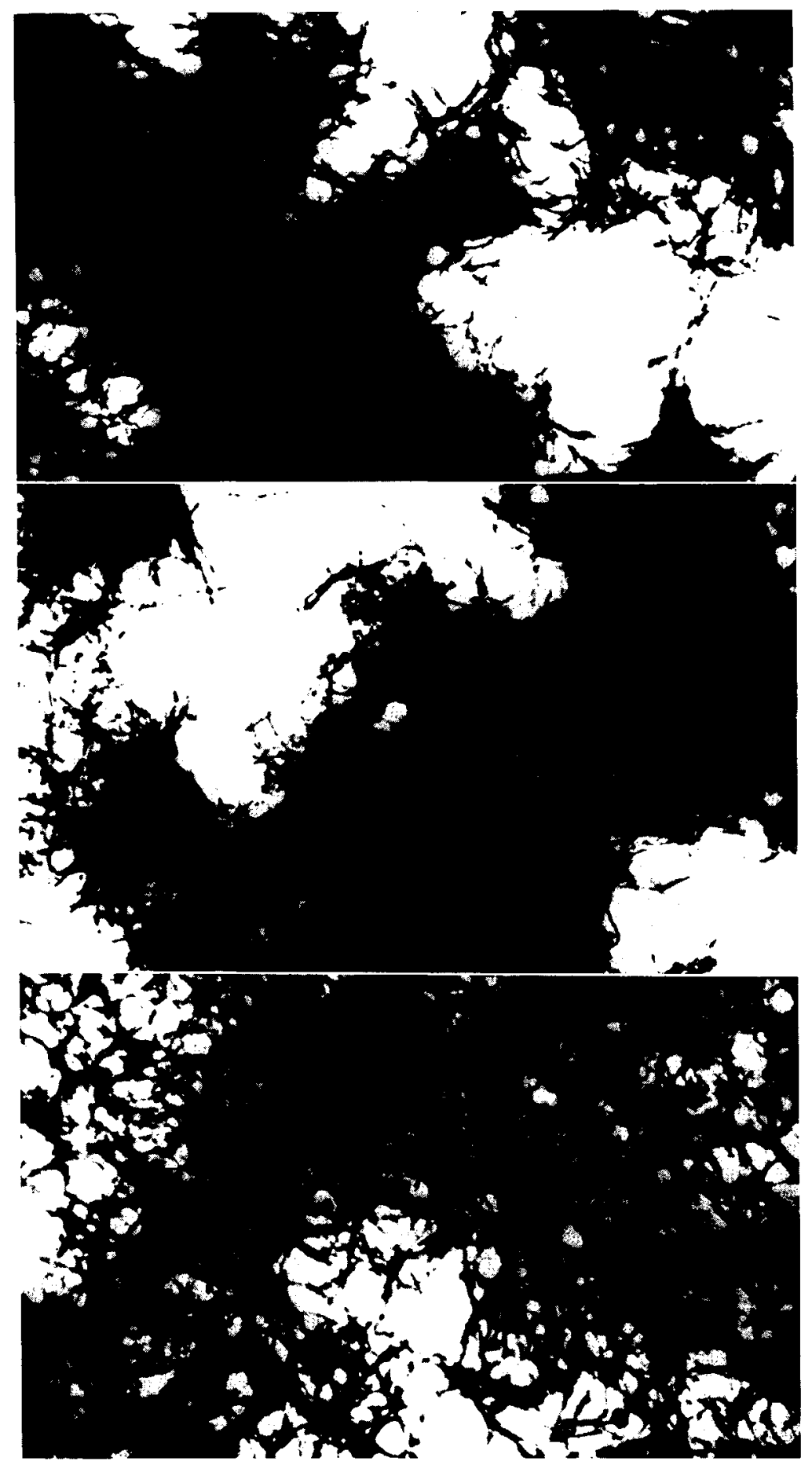

Fig. 1 Growth status of $M$. lepraemurium in NC-5 medium: upper; Hawaii, middle; Kurume No. 42, lower; Kumamoto strain. 
すべきである。

ただ NC 培地よりも NC-5培地がはるかに優ると思 われる点は鼠睓菌 3 株の増菌が NC 培地では著しい優 劣があるのに NC-5培地では 3 株とも比較的均一に増殖 することであった。

菌株によって増殖に差があるのは菌株そのもののもつ 特性であるのは勿論であって in vivo の増殖曲線の差 もこれによって生じるものである。 $\mathrm{C}_{3} \mathrm{H}$ マウスの足蹠 での增殖曲線より算出された generation time ${ }^{6}$ 㳉，八 ワイ株は 3.8 日，久留米 42 号株は 4.4 日，熊本株は 10.1 日であった。この data とこの NC-5培地での増殖度の 差が一致したことは興味梁い。すなわち NC-5培地で観 察された増殖度はハワイ株と久留米42号株は殆んど同一 で熊本株はやや劣ったのである。しかし，一方 in vitro での菌の増殖はその接種量にも非常に影響されるので本 報ではスライドへの塗抹量が一定化されていないため， 一概に菌株の特性とは規定しがたく，感染組織の含有量 も考虑されねばならない。ただ，菌株間の增殖率に著し い差がないことが増菌用培地としては当然すぐれている 訳でこの点からして NC-5 培地が NC 培地よりかなり 所期の目的に近づいたものといらことが出来よう。

\section{結 譣}

NC-3 培地の基礎培地より瞢桾を除き，l-システィン 塩酸塩を加えて NC-3培地を改良しこれを NC-5培地と 呼称した。
この培地に鼠瀨菌，ハワイ株，久留米42号株および熊 本株を培養すると著明な増菌像がほぼ均一に観察され た。

\section{謝辞}

本研究の一部は日米医学協力会議ライ専門部会研究費 によった。技術的援助をいただいた境美鶴・岡田敏子技 手補に謝意を表す。

\section{文献}

1) 中村昌弘：無細胞培地飞括ける鼠痳菌の增菌, 第 4 報， NC-3培地の開発，レプラ，42, 161-164 (1973).

2）中村昌弘：無緗胞液体培地に㧍ける鼠瀨菌の增 菌，第 1 報， NC 培地の開発，レプラ，42，4751 (1973).

3) Nakamura, M.: Multiplication of Mycobacterium lepraemurium in cell-free medium containing $\alpha$-ketoglutaric acid and cy tocrome C. J. gen. Microbiology, 73, 193-195 (1972).

4) 中村昌弘：ホズミライ菌増菌用 NC 培地の改 良 (NC-5培地)，医学のあゆみ，83，201-202 (1972).

5) Nakamura, M.: Multiplication of Mycobacterium lepraemurium in cell-free liquid medium. Proc. Japan Academy, 49, 42-46 (1973).

6) 中村昌弘・金川貞子：ネズミライ菌 4 株の dd 系及び $\mathrm{C}_{3} \mathrm{H}$ 系マウスに㧍汀る増菌曲線と世代 時間，レプラ，40，179-183 (1971). 